\title{
Supply Chain Management Pengolahan Pangan Penerima KJP di Pasar Jaya Wilayah Mampang Prapatan Berbasis Web
}

\author{
Hana Firyal ${ }^{1}$, Erly Krisnanik ${ }^{2}$, I Wayan Widi Pradnyana ${ }^{3}$ \\ S1 Sistem Informasi, Fakultas Ilmu Komputer \\ Universitas Pembangunan Nasional Veteran Jakarta \\ hanafiryal13@gmail.com¹, erlykrisnanik@gmail.com², wayan.widi@upnvj.ac.id ${ }^{3}$.
}

\begin{abstract}
Abstrak. Supply Chain Management merupakan suatu metode untuk membantu perusahaan dalam mengkoordinasi alur manajemen logistik hingga sampai ke pihak terakhir atau konsumen. Koordinasi ini tidak hanya terdapat di dalam suatu aktivitas perusahaan, tetapi juga untuk aktivitas yang terdapat di luar perusahaan. Pasar merupakan salah satu dari aktor yang terlibat pada alur Supply Chain Management ini. Untuk mendukung kelancaran persediaan pangan pada pasar hingga sampai ke konsumen maka diperlukannya koordinasi dari semua pihak yang terlibat. Namun, pada pasar jaya ini pengolahan persediaan pangan masih bersifat manual serta tidak adanya informasi mengenai stok pangan yang tersedia jika penerima KJP tidak menanyakan secara langsung. Maka dari itu dalam mengatur pengolahan persediaan pangan perlu diadakannya sistem untuk mengatur seluruh informasi yang menyangkup persediaan pangan. Sistem Persediaan Pangan ini meliputi informasi data masuk dan keluarnya pangan, mempermudah pengontrolan persediaan stok pangan serta mempermudah pembuatan laporan. Sistem ini akan dibuat menggunakan metode prototype serta menggunakan framework codeigniter dalam perancangannya. Yang dihasilkan dari penelitian ini berupa sistem pengolahan pangan yang berbasis web yang dapat mengatur serta mempermudah pihak pergudangan melakukan pengolahan data pangan masuk dan keluar, dan data stok pangan yang ada di gudang.
\end{abstract}

Kata Kunci : Supply Chain Management, Pasar, Persedian Pangan, Sistem.

\section{Pendahuluan}

Di dalam suatu perusahaan proses persediaan bahan atau produk dari supplier merupakan puncak keberhasilan dari perusahaan tersebut. Oleh karena itu, perlu diadakannya cara untuk mempermudah proses tersebut. supply chain management merupakan sekumpulan perusahaan yang saling berkerjasama untuk membuat dan mengantarkan suatu produk hingga sampai ke pemakai atau konsumen. supply chain management merupakan hubungan beberapa proses bisnis dalam penyaluran produk yang mencangkup kegiatan perencanaan dan pengolahan dari aktivitas pengadaan dan logistik serta informasi yang berkaitan dengan mulainya pembuatan bahan baku hingga sampai ke pemakain atau konsumen, termasuk koordinasi serta kolaborasi dengan jaringan mitra usaha.

Pasar pada umumnya merupakan suatu tempat terjadinya transaksi berlangsung serta tempat titik temunya para pedagang dan pembeli. Seiring dengan berjalannya waktu dan adanya tuntutan konsumen pasar yang terus berubah, maka pasar tidak hanya menjadi tempat bertemunya para pedagang dengan konsumen. Pasar sudah menjadi bagian dari bisnis yang lengkap, dimana kenyamanan dan kepuasan dari pelanggan yang menjadi tujuan utamanya. Pasar Jaya merupakan Perusahaan Daerah yang dimiliki oleh Pemerintah Provinsi DKI Jakarta, dimana tugasnya untuk melaksanakan kegiatan pelayanan umum pada bidang pengolahan area pasar, pembinaan pada pedagang pasar, ikut membantu menstabilitakan harga dan kelancaran pendistribusian barang maupun jasa.

PD Pasar Jaya adalah sebagai salah satu BUMD DKI Jakarta yang mendapatkan tugas dalam pendistribusian pangan murah untuk penerima KJP, PPSU, penghuni rusun pemda dan seterusnya. Pangan murah yang didistribusikan ke para penerimanya melalui PD Pasar Jaya adalah berupa beras, daging sapi, daging ayam, ikan, telur, dan susu. Setiap penerimanya dapat membeli semua pangan yang disediakan sebanyak 1 kali untuk setiap bulannya di Pasar Jaya. Pasar Jaya di wilayah Mampang Prapatan merupakan salah satu dari pasar yang dimiliki oleh PD Pasar Jaya sebagai wadah pendistribusian pangan murah khusus penerima KJP di wilayah Mampang Prapatan dan sekitarnya.

Pasar Jaya di wilayah Mampang Prapatan ini memiliki pergudangan untuk menyimpan pangan dan melayani pembelian pangan murah khusus untuk penerima KJP. Pada pergudangan di Pasar Jaya ini pengolahan persediaan pangannya masih bersifat manual untuk pencatatan dan pengontrolan stok pangan. Dalam hal pencatatan penjualan pangan sebatas menggunakan aplikasi sederhana seperti Microsoft Excel dimana laporan yang telah di buat dan disimpan di komputer dapat hilang sewaktu-waktu jika file simpanannya corrupt, terhapus atau hilang. Serta penerima KJP yang ingin membeli pangan tidak dapat mengetahui jumlah stok pangan yang diinginkan jika tidak mendatangi Pasar Jaya. Melihat kendala tersebut, perlu adanya sistem yang mengatur pergudangan pada Pasar Jaya ini. 


\section{JURNAL INFORMATIK Edisi ke-16, Nomor 3, Desember}

Oleh karena itu, penelitian yang penulis lakukan ini untuk dapat membuat sebuah aplikasi pengolahan pangan penerima KJP berbasis web yang berfungsi memudahkan pengolahan data pangan masuk dan keluar, pencatatan penjualan yang efektif, serta menginformasikan stok pangan yang tersedia digudang ke penerima KJP.

Manfaat yang didapat dari perancangan sistem supply chain management pengolahan pangan penerima KJP di Pasar Jaya wilayah Mampang Prapatan berbasis web ini adalah :

1) Membantu pegawai pihak pergudangan dalam memproses pengolahan dari data stok pangan yang masuk dan keluar, sehingga mempermudah pegawai dalam memberikan informasi.

2) Penerima KJP dapat mengetahui stok pangan yang tersedia tanpa harus mendatangi ke pasar.

3) Untuk menunjang kinerja pihak pergudangan karena telah terkomputerisasinya proses pengolahan data. Untuk mempermudah pihak pergudangan dalam pembuatan laporan data penjualan pangan setiap bulannya.

\section{Teori}

Menurut Mentzer dkk. Dalam buku I Nyoman Pujawan dan Mahendrawathi Er (2017:7) supply chain management merupakan metode perencanaan dan seluruh manajemen logistik meliputi koordinasi dan kolaborasi dengan supplier, distributor, dan layanan pihak ketiga. Sedangkan menurut Arif (2018:7) supply chain management adalah suatu konsep pola dari pendistribusian baru yang dapat menggantikan pola dari pendistribusian produk yang terdahulu.

Pada dasarnya supply chain management terdiri atas proses bisnis suatu perusahaan yang berjalan seiring dengan sifat siklus yang berjalan secara terus menerus. Yang mencakup :

1) Aliran material yaitu suatu produk dari supplier ke customer termasuk retur, service, recycling dan pembuangan merupakan aliran yang termasuk dalam siklus.

2) Aliran informasi yaitu pembelian dan lampiran status pengiriman barang merupakan suatu transmisi yang terliput pada siklus.

Aliran keuangan yaitu suatu siklus yang meliputi informasi kartu kredit, syarat dan jadwal pembayaran.

Tujuan dari supply chain management adalah untuk dapat memenuhi permintaan pelanggang dengan melalui efektifitas dan efesiensi yang terdiri dari pemasok, perusahaan pabrik, gudang dan toko.

Aktivitas dari supply chain management dapat dimulai dari pembelian bahan baku dan bahan mentah yang sampai ke pihak supplier untuk selanjutnya diproduksi di dalam pabrik hingga menjadi produk jadi yang kemudian didistribusi ke customer. Para pedagang besar yang memiliki gudang akan menyimpan barang-barangnya tersebut di gudang sebelum disalurkan kembali ke pihak pengecer. Lalu pihak pengecer atau retail akan menawarkan produk tersebut kepada pembeli atau pengguna.

Supply chain management memiliki komponen dasar yang dapat dilihat dari 2 bagian, yaitu:

1) Upstream Supply Chain

Upstream merupakan suatu siklus yang berhubungan antara supplier dan perusahaan serta meliputi aktivitas pengadaan bahan baku. Pengadaan adalah aktivitas yang utama dari upstream.

2) Downstream Supply Chain

Downstream merupakan suatu kegiatan dari perusahaan ke customer, meliputi aktivitas pengenalan dan pemasaran produk serta pendistribusi produk ke customer akhir. Kegiatan yang difokuskan pada downstream adalah pendistribusi, pergudangan, transportasi, dan after sales service.

\section{Metodologi Penelitian}

Pada metodologi penelitian ini, tapan penelitian yang digunakan oleh penulis adalah menggunakan metode perancangan prototyping menurut Pressman (2010:43).

Uraian proses tahapan penelitian pada Gambar 1 adalah sebagai berikut:

a. Studi Literatur, Penulis melakukan pencarian informasi terkait dengan topik dan masalah yang menjadi obyek penelitian. Pencarian informasi dapat diperoleh dari buku-buku, jurnal, internet dan sumber lainnya.

b. Communication (Komunikasi), Kegiatan yang akan dilakukan oleh penulis pada tahapan communication (komunikasi) adalah dengan berkomunikasi secara langsung dengan pihak dari Pasar Jaya wilayah Mampang Prapatan, untuk mendapatkan gambaran dalam membangun suatu sistem yang baik. Disini Penulis melakukan komunkasi secara langsung dengan pegawai dan kepala Pasar Jaya wilayah Mampang Prapatan serta mengumpulkan data. Metode dalam pengumpulan data yang digunakan penulis dalam penelitian ini menggunakn observasi dan wawancara. 


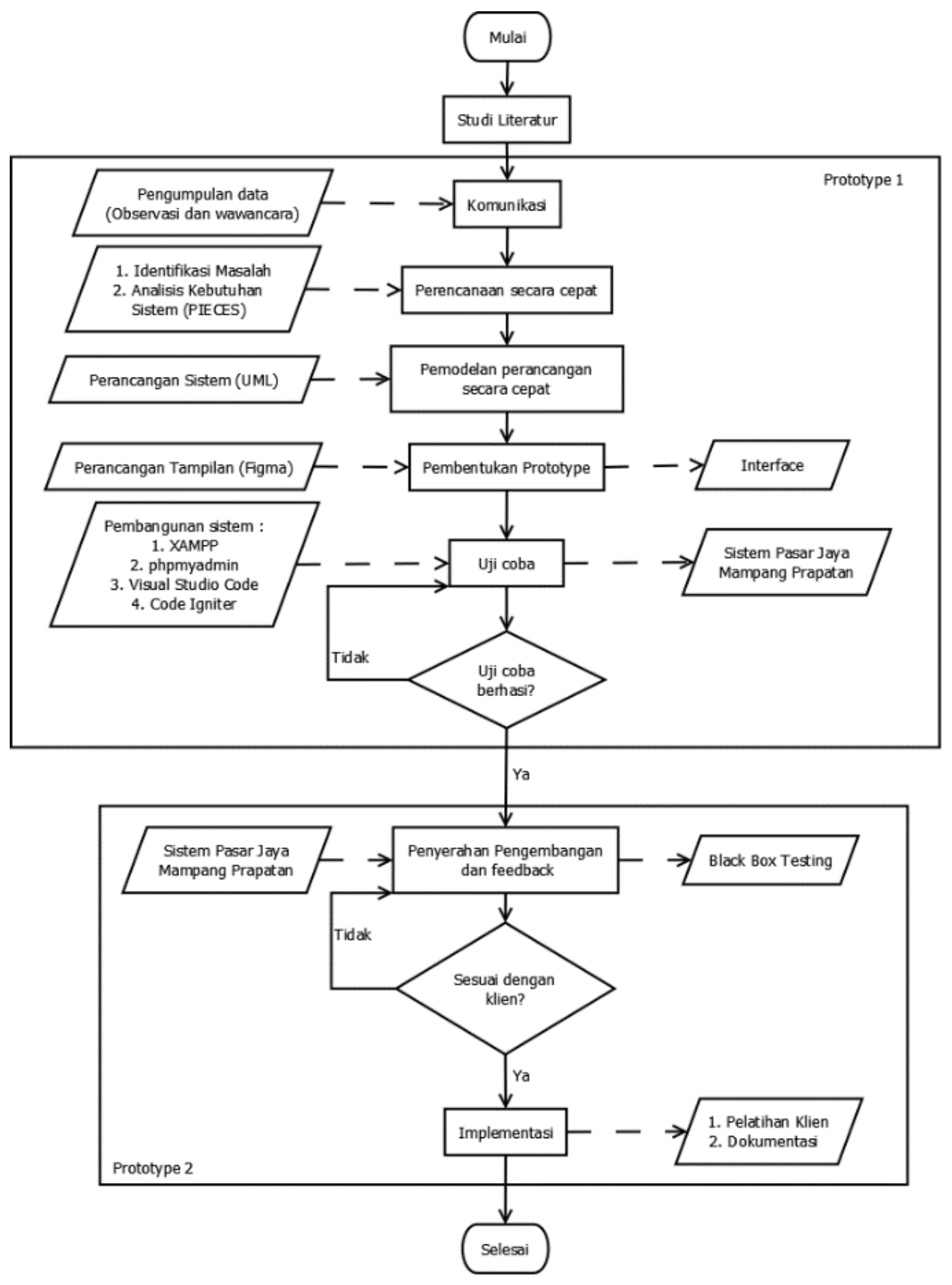

Gambar 1. Metodologi Penelitian

c. Quick Planning (Perencanaan secara cepat), Kegiatan yang akan dilakukan oleh penulis pada tahap quick planning (perencanaan secara cepat) adalah dengan melakukan perencanaan kebutuhan, serta menganalisis sistem yang akan dibuat dengan menggunakan metode PIECES.

d. Modeling Quick Design (Pemodelan perancangan secara cepat), Kegiatan yang akan dilakukan oleh penulis pada tahap modeling quick design (pemodelan perancangan secara cepat) adalah melakukan perancangan desain pemodelan alur sistem dengan menggunakan UML (Unified Modeling Language).

e. Construction of Prototype (Pembentukan prototype), Kegiatan yang akan dilakukan oleh penulis pada tahap construction of prototype (pembentukan prototype) adalah melakukan perancangan prototype yang menggunakan Figma, perancangan ini meliputi pembuatan halaman interface untuk user. 
f. Uji Coba, Kegiatan yang akan dilakukan oleh penulis pada tahap uji coba adalah melakukan pembangunan sistem serta uji coba sistem Pasar Jaya Mampang Prapatan untuk dapat memastikan sistem yang dibuat berhasil atau tidak.

g. Deployment Delivery \& feedback (Penyerahan Pengembangan dan feedback), Kegiatan yang akan dilakukan oleh penulis pada tahap deployment delivery \& feedback (penyerahan pengembangan dan feedback) adalah melakukan penyerahan sistem yang sudah selesai kepada klien agar digunakan untuk mendapatkan feedback dari klien tentang bagaimana sistem yang telah selesai dirancang. kemudian dilakukan test fungsi sistem menggunakan Black Box Testing untuk mengetahui error atau tidaknya sistem tersebut.

h. Implementasi, Kegiatan yang akan dilakukan oleh penulis pada tahap implementasi adalah dokumentasi untuk mencatatkan tahapan dari setiap perancangan dari sistem yang dilakukan hingga sampai ditahap uji coba sistem, sehingga dapat terpantau dengan baik dan menghasilkan panduan bagi penguna. Serta pelatihan kepada user untuk dapat menggunakan sistem dengan baik dan benar.

\section{Hasil Dan Pembahasan}

\subsection{Quick Planning (Perencanaan secara cepat)}

a. Use Case Sistem Berjalan

Berikut ini merupakan gambar use case sistem berjalan berdasarkan identifikasi masalah yang penulis jelaskan di atas.

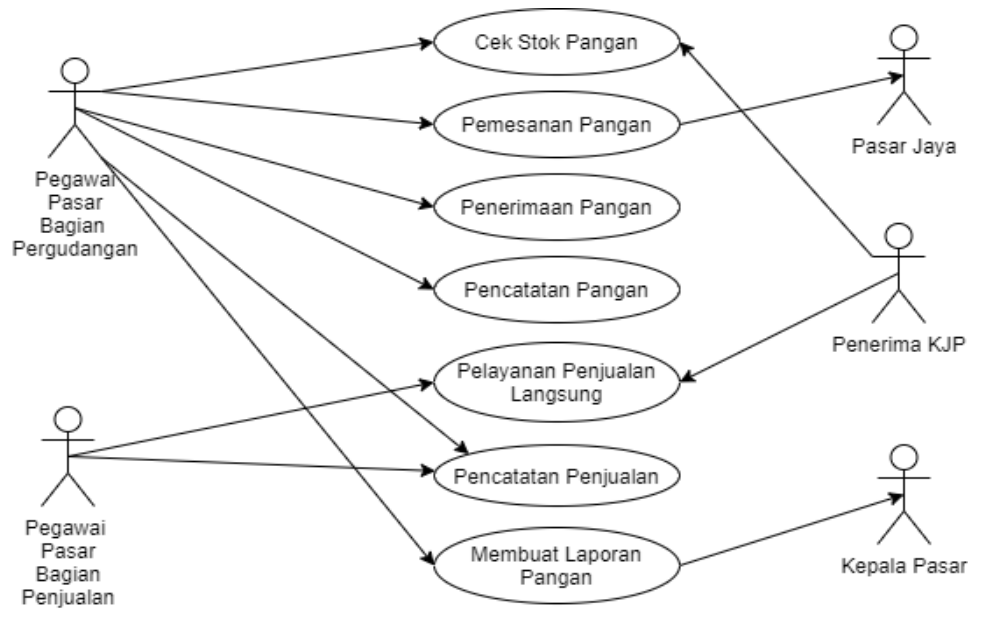

Gambar 2. Use case Sistem berjalan

\section{b. Identifikasi Masalah}

Setelah mempelajari dan menganalisis cara kerja pada sistem berjalan di Pasar Jaya Mampang Prapatan, maka berikut merupakan hasil dari analisis sistem usulan yang dijelaskan dengan menggunakan metode PIECES menurut Rohmat Taufiq (2013:154) :

1) Performance

Proses pencatatan data penjualan pangan yang masih menggunakan cara konvesional dan kemudian dicatat kembali ke aplikasi sederhana (Microsoft Excel) belum bisa memberikan kinerja yang baik. Sementara itu, proses pencatatan data pangan sudah menggunakan aplikasi sederhana (Microsoft Excel) dapat memberikan kinerja yang cukup baik.

\section{2) Information}

Terkait informasi, proses pencatatan data penjualan pangan yang berjalan konvensional sebelum dicatat kembali ke aplikasi sederhana (Microsoft Excel) dapat menyebabkan kesalahan informasi seperti informasi penjulan serta mempengaruhi informasi stok pangan yang tersedia. Sementara itu, dalam proses pencatatan data pangan yang sudah menggunakan aplikasi sederhana (Microsoft Excel) sudah dapat memberikan informasi pangan yang masuk cukup akurat.

3) Economic 


\section{JURNAL INFORMATIK Edisi ke-16, Nomor 3, Desember}

Pada sistem berjalan yang sudah ada ini dapat dikatakan tidak ekonomis, tetapi penggunaan media kertas dalam pencatatan pada proses penjualan pangan menimbulkan pengeluaran yang cukup banyak.

4) Control

Proses pengarsipan data pangan dan data penjualan pangan yang dilakukan dengan menggunakan aplikasi sederhana (Microsoft Excel) sudah dapat dikatakan cukup baik, tapi dapat ditingkatkan lagi dengan penggunaan database agar penyimpanan data lebih terstruktur.

5) Efficiency

Proses pencatatan penjual pangan masih belum dapat dikatakan efisien karena proses pencatatan penjualan dilakukan dua kali, yaitu secara konvensional kemudian dicatatat kembali ke aplikasi sederhana (Microsoft Excel).

6) Service

Pada aspek service ini belum dapat dikatakan bagus untuk menginformasikan terkait stok pangan

c. Masalah Pokok kepada penerima KJP, dikarenakan penerima KJP harus mendatangi ke pasar jaya mampang.

1) Tidak terkomputerisasinya data pangan di Pasar Jaya Mampang, mengakibatkan pencatatan pangan harus dilakukan dengan manual terlebih dahulu sebelum disalin ke Microsoft Excel.

2) Pencatatan penjualan pangan yang masih secara konvensional dan kemudian dicatat kembali ke aplikasi sederhana (Microsoft Excel), belum dikatakan efisien karena masih memakan banyak waktu, dan rentan terhadap human error.

3) Tidak adanya informasi tentang stok pangan yang tersedia di pasar jaya mampang ini mengakibatkan penerima KJP harus datang terlebih dahulu untuk menanyakan terkait stok pangan yang tersedia.

\section{d. Solusi Pemecahan Masalah}

1) Terkomputerisasinya data pangan pada pasar jaya mampang dengan supplier, agar mempermudah dalam pengadaan pangan / mempermudah pemesanan pangan.

2) Pencatatan penjualan pangan akan terdapat di dalam fitur penjualan, dimana di fitur ini transaksi penjualan akan tercatat dengan rapih dan terstruktur.

3) Adanya fitur home yang dapat digunakan sebagai media informasi bagi penerima KJP untuk mengetahui informasi terkait stok pangan dan tanpa harus melakukan pebuatan akun / login ke sistem.

\section{e. Analisis Kebutuhan}

1) Analisis Kebutuhan Pengguna

Pihak-pihak yang akan terlibat di dalam sistem usulan adalah sebagai berikut.

a) Pihak Pergudangan

Pihak pergudangan merupakan seorang pegawai pasar yang berlaku sebagai admin atau orang yang memiliki hak akses tertinggi dalam suatu sistem dan memiliki wewenang serta memiliki tanggung jawab dalam mengelolah sistem. Tugas utamanya adalah mengelolah data master (data pegawai pasar, data supplier, data penerima KJP, dan data pangan), mengelolah pengadaan pangan (data pemesanan, data penerimaan pangan dan data pengembalian pangan), mengelolah data transaksi penjualan, serta membuat laporan.

b) Supplier

Supplier adalah pihak yang bertugas untuk menyediakan pangan yang akan dikirimkan ke pasar jaya mampang untuk disalurkan ke penerima KJP. Supplier dapat melihat stok yang terdapat pada pasar jaya, dapat melihat data pemesanan, dapat melihat data pengembalian pangan dan mendapatkan notifikasi jika stok sudah dibatas minimum.

c) Pihak Penjualan

Pihak penjualan merupakan seorang pegawai pasar yang bertugas melakukan pencatatan dan melayani penjualan pangan di pasar jaya mampang prapatan.

d) Penerima KJP

Penerima KJP adalah orang yang memiliki KJP atau yang terdaftar sebagai pemegang KJP. Di dalam sistem, penerima KJP dapat langsung mengujungi halaman beranda sistem tanpa harus login. Serta penerima KJP dapat memberikan masukan terkait pangan apa yang akan penerima 
KJP inginkan untuk dibeli sebagai acuan untuk pihak gudang melakukan pemesanan tambahan atau tidak ke supplier.

e) Kepala Pasar

Kepala pasar merupakan orang yang mendapatkan laporan stok pangan, dan penjualan pangan di pasar jaya mampang.

2) Analisis Kebutuhan Data

Berdasarkan analisis kebutuhan pengguna yang telah dilakukan, dapat dijabarkan kebutuhan data yang diperlukan untuk sistem usulan sebagai berikut.

a) Data Pengguna

Data pihak pengguna yang berfungsi sebagai data para pengguna untuk dapat melakukan login ke sistem sebagai admin yang memiliki seluruh akses yang ada pada sistem, sebagai supplier untuk melihat data pemesanan dan pengembalian, sebagai pegawai untuk mengelolah transaksi penjualan, dan sebagai kepala pasar untuk mengetahui laporan pangan.

b) Data Pegawai

Data pegawai berfungsi sebagai data profil dari pegawai pasar yang berkaitangan dengan pengolahan pangan.

c) Data Supplier

Data supplier berfungsi berfungsi data profil dari pemasok pangan pada Pasar Jaya untuk disalurkan ke penerima KJP.

d) Data Penerima KJP

Data penerima KJP berfungsi mencatat data penerima KJP. Data penerima KJP juga berfungsi sebagai acuan jika Penerima KJP ini masih aktif dan terdaftar.

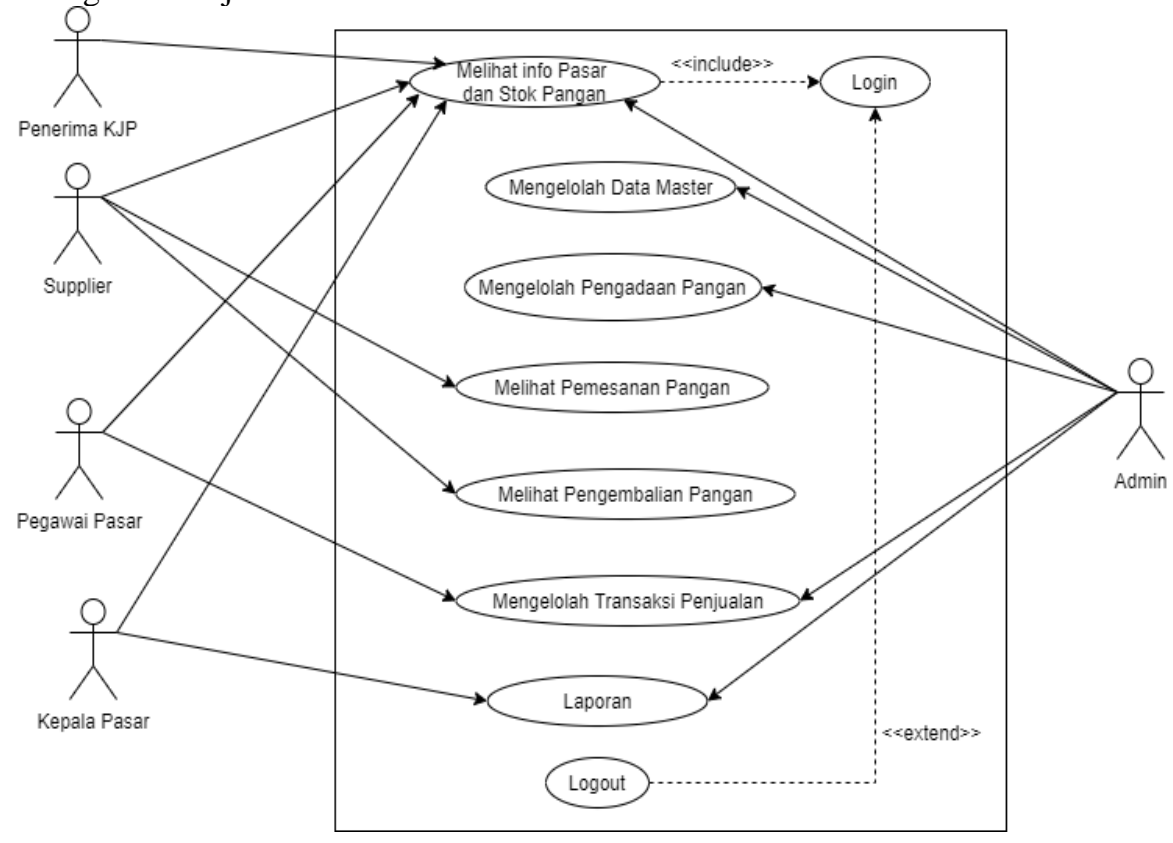

Gambar 3. Use Case Usulan

e) Data Pemesanan Pangan

Data pemesanan pangan berfungsi sebagai data yang merincikan perihal informasi pangan yang akan di pesan ke supplier.

f) Data Penerimaan Pangan

Data penerimaan pangan berfungsi sebagai data yang menginformasikan tentang penerimaan pangan yang diterima oleh pasar jaya mampang.

g) Data Pengembalian Pangan 
Data pengembalian pangan berfungsi sebagai data yang merincikan perihal informasi barang yang rusak, dan akan dikembalikan ke supplier.

h) Data Pangan

Data pangan berfungsi untuk memberikan informasi banyak pangan yang tersedia di gudang. Data pangan ini juga berfungsi sebagai tolak ukur untuk menghitung stok pangan yang tersedia dan melakukan pemesanan ke supplier.

i) Data Transaksi Penjualan

Data transaksi penjualan berfungsi untuk memberikan informasi terkait transaksi yang dilakukan oleh pembeli.

j) Data Detail Transaksi

Data detail transaksi berfungsi untuk memberikan informasi terkait transaksi pangan yang sudah terjual sebagai acuan informasi stok yang tersedia.

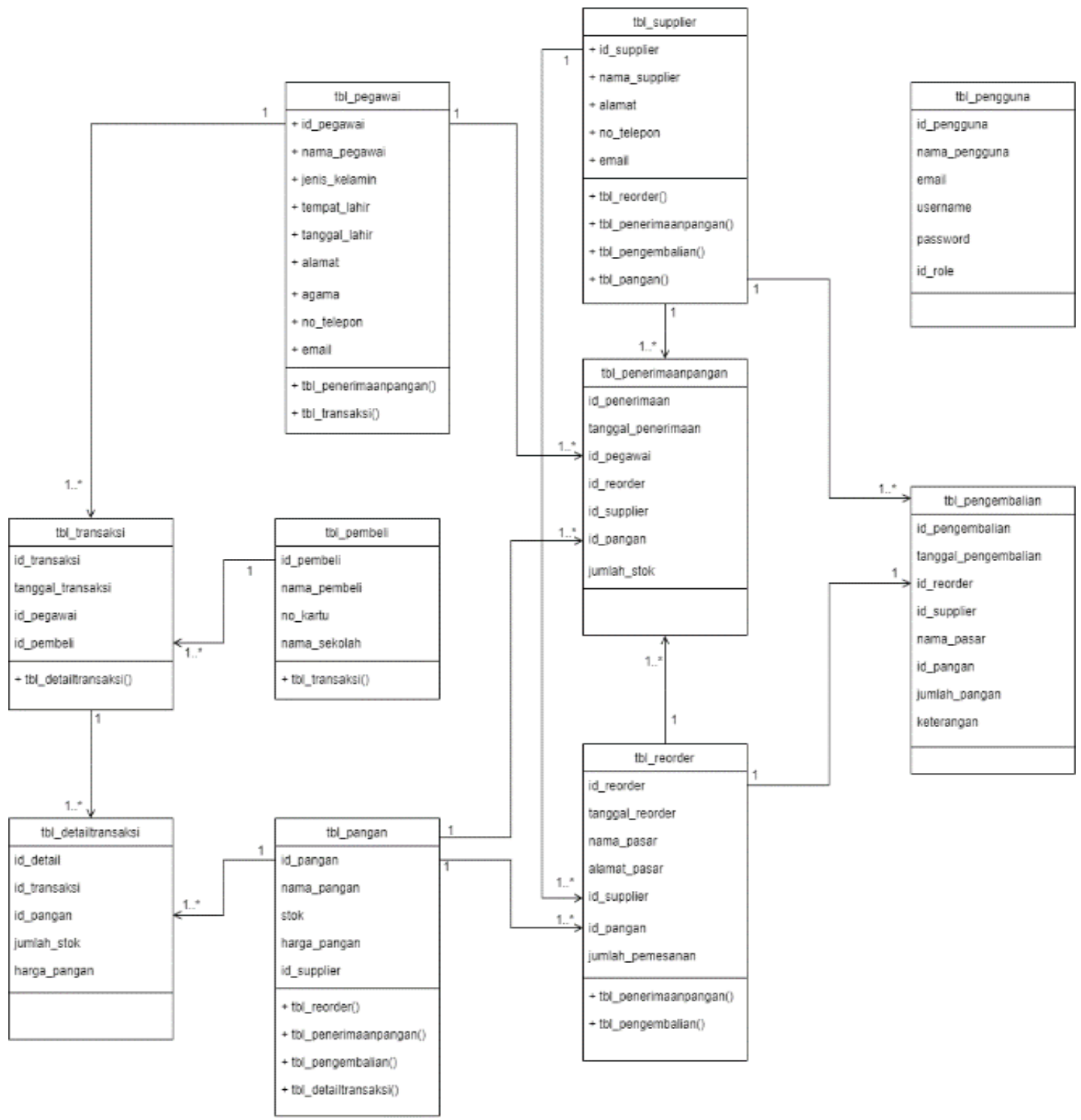

Gambar 4. Class Diagram

ISSN : 2655-139X (ONLINE)

ISSN : 0216-4221 (PRINT) 


\subsection{Modeling Quick Design (Pemodelan perancangan secara cepat)}

a. Use Case Usulan

Gambar 3 merupakan gambar use case sistem usulan berdasarkan identifikasi masalah yang penulis jelaskan di atas.

\section{b. Class Diagram}

Gambar 4 berikut ini merupakan gambar class diagram sistem usulan yang penulis usulkan pada sistem supply chain management pengolahan pangan penerima KJP di Pasar Jaya wilayah Mampang Prapatan berbasis Web.

\subsection{Construction of Prototype (Pembentukan prototype)}

a. Rancangan Dokumen

1) Rancangan Dokumen Masukan Sistem Usulan

Berikut ini merupakan rancangan dokumen masukan yang diusulkan untuk sistem supply chain management pengolahan pangan penerima KJP di Pasar Jaya wilayah Mampang Prapatan berbasis web.

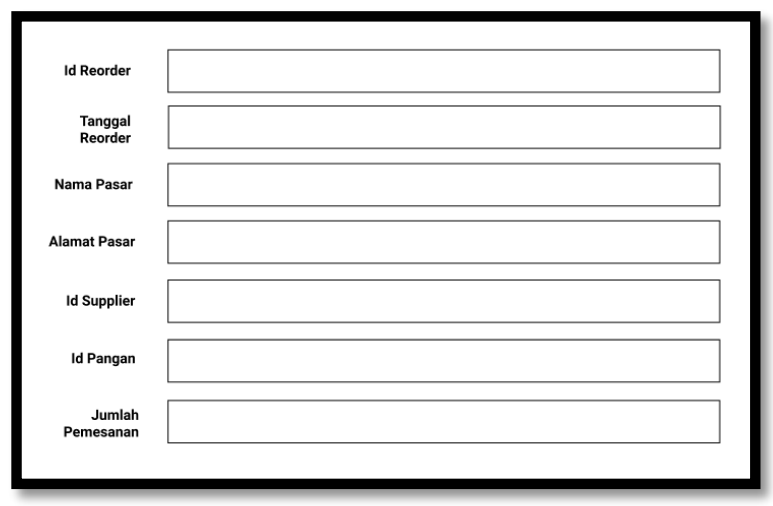

Gambar 5. Rancangan Dokumen Masukan Pemesanan Pangan

2) Rancangan Dokumen Keluaran Sistem Usulan

Berikut ini merupakan rancangan dokumen keluaran yang diusulkan untuk sistem supply chain management pengolahan pangan penerima KJP di Pasar Jaya wilayah Mampang Prapatan berbasis web.

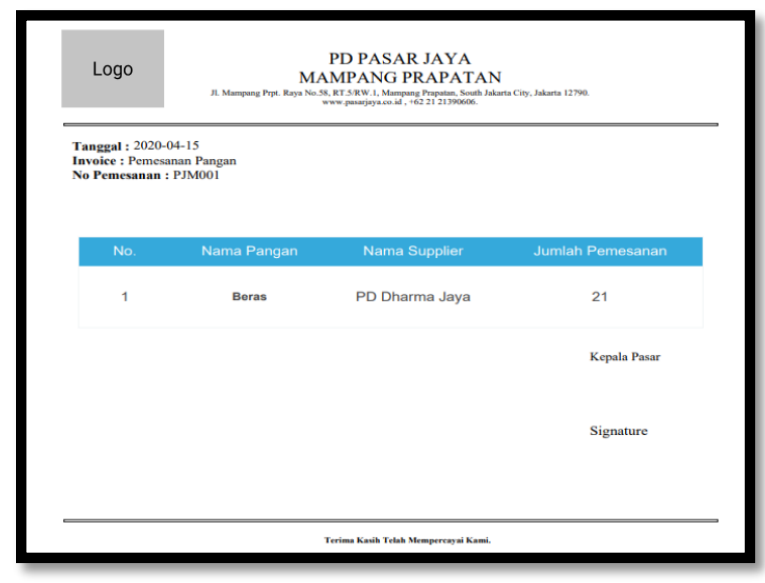

Gambar 6. Rancangan Dokumen Keluaran Pemesanan Pangan 
b. Rancangan Interface

Berikut ini merupakan gambar rancangan interface sistem usulan yang penulis usulkan.

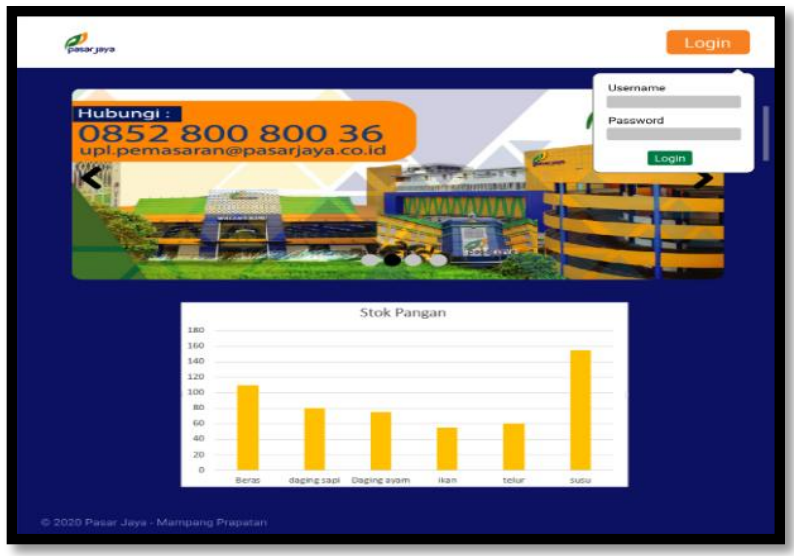

Gambar 7. Rancangan Home

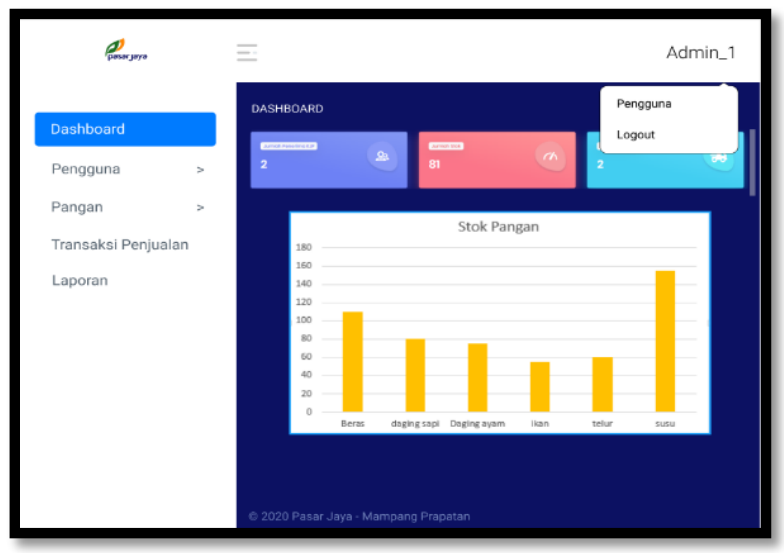

Gambar 8. Rancangan Dashboard

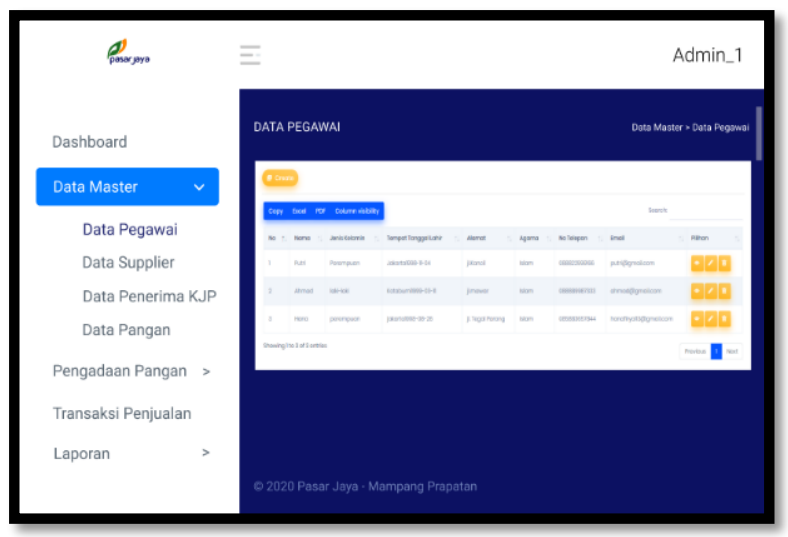

Gambar 9. Rancangan Data Pegawai 


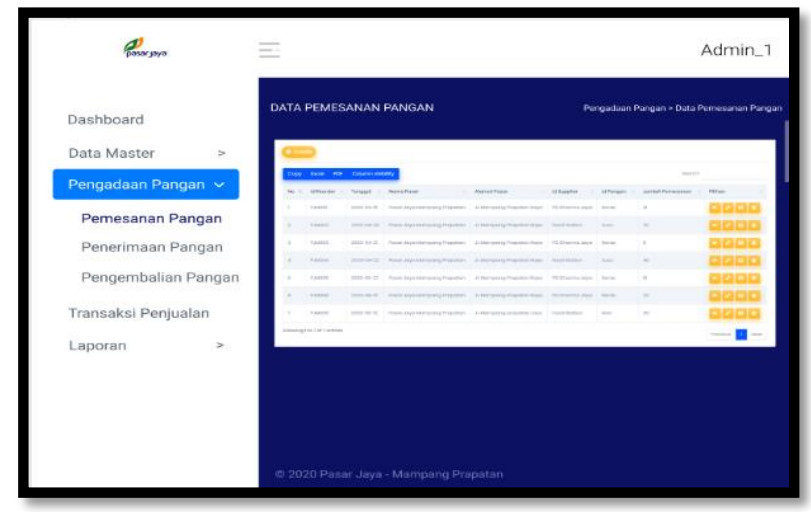

Gambar 10. Rancangan Data Pemesanan Pangan

\subsection{Deployment Delivery \& feedback (Penyerahan Pengembangan dan feedback)}

\section{a. Hasil Pengujian Sistem}

Berikut ini merupakan tabel pengujian sistem usulan berupa sekumpulan skenario dari kegiatan yang terdapat pada sistem untuk mengetahui apakah sistem berjalan sesuai rencana atau tidak, dengan menggunakan metode Black box Testing.

Tabel 1. Pengujian Sistem

\begin{tabular}{|c|l|l|l|l|l|}
\hline No & Nama Proses & \multicolumn{1}{|c|}{ Aktor } & \multicolumn{1}{c|}{ Aksi } & \multicolumn{1}{c|}{$\begin{array}{c}\text { Hasil yang } \\
\text { diharapkan }\end{array}$} & Hasil \\
\hline 1. & Login & $\begin{array}{l}\text { Admin, Supplier, } \\
\text { Pegawai Pasar, } \\
\text { Kepala Pasar }\end{array}$ & $\begin{array}{l}\text { Mengautentikasi diri } \\
\text { ke dalam sistem }\end{array}$ & $\begin{array}{l}\text { Masuk ke dalam } \\
\text { sistem }\end{array}$ & Berhasil \\
\hline 2. & $\begin{array}{l}\text { Mengelolah } \\
\text { data } \\
\text { pengguna }\end{array}$ & Admin & $\begin{array}{l}\text { Menambahkan, } \\
\text { mengubah, dan } \\
\text { menghapus data } \\
\text { pengguna }\end{array}$ & $\begin{array}{l}\text { Dapat menambahkan, } \\
\text { mengubah, dan } \\
\text { menghapus data } \\
\text { pengguna }\end{array}$ & Berhasil \\
\hline 3. & $\begin{array}{l}\text { Mengelolah } \\
\text { data pegawai }\end{array}$ & Admin & $\begin{array}{l}\text { Menambahkan, } \\
\text { melihat detail, } \\
\text { mengubah, dan } \\
\text { menghapus data } \\
\text { pegawai }\end{array}$ & $\begin{array}{l}\text { Dapat menambahkan, } \\
\text { melihat detail, } \\
\text { mengubah, dan } \\
\text { menghapus data } \\
\text { pegawai }\end{array}$ & Berhasil \\
\hline 4. & $\begin{array}{l}\text { Mengelolah } \\
\text { data supplier }\end{array}$ & Admin & $\begin{array}{l}\text { Menambahkan, } \\
\text { melihat detail, } \\
\text { mengubah, dan } \\
\text { menghapus data } \\
\text { supplier }\end{array}$ & $\begin{array}{l}\text { Dapat menambahkan, } \\
\text { melihat detail, } \\
\text { mengubah, dan } \\
\text { menghapus data } \\
\text { supplier }\end{array}$ & Berhasil \\
\hline 5. & $\begin{array}{l}\text { Mengelolah } \\
\text { data penerima } \\
\text { KJP }\end{array}$ & Admin & $\begin{array}{l}\text { Menambahkan, } \\
\text { melihat detail, } \\
\text { mengubah, dan } \\
\text { menghapus data } \\
\text { penerima KJP }\end{array}$ & $\begin{array}{l}\text { Dapat menambahkan, } \\
\text { melihat detail, } \\
\text { mengubah, dan } \\
\text { menghapus data } \\
\text { penerima KJP }\end{array}$ & Berhasil \\
\hline 6. & $\begin{array}{l}\text { Mengelolah } \\
\text { mata pangan } \\
\text { melihat detail, } \\
\text { mengubah, dan } \\
\text { menghapus data } \\
\text { pangan }\end{array}$ & $\begin{array}{l}\text { Dapat menambahkan, } \\
\text { melihat detail, } \\
\text { mengubah, dan } \\
\text { menghapus data } \\
\text { pangan }\end{array}$ & Berhasil \\
\hline
\end{tabular}




\begin{tabular}{|c|c|c|c|c|c|}
\hline 7. & $\begin{array}{l}\text { Mengelolah } \\
\text { pemesanan } \\
\text { pangan }\end{array}$ & Admin & $\begin{array}{l}\text { Menambahkan, } \\
\text { melihat detail, } \\
\text { mengubah, dan } \\
\text { menghapus data } \\
\text { pemesanan pangan }\end{array}$ & $\begin{array}{l}\text { Dapat menambahkan, } \\
\text { melihat detail, } \\
\text { mengubah, dan } \\
\text { menghapus data } \\
\text { pemesanan pangan }\end{array}$ & Berhasil \\
\hline 8. & $\begin{array}{l}\text { Mengelolah } \\
\text { penerimaan } \\
\text { pangan }\end{array}$ & Admin & $\begin{array}{l}\text { Menambahkan, } \\
\text { melihat detail, } \\
\text { mengubah, dan } \\
\text { menghapus data } \\
\text { penerimaan pangan }\end{array}$ & $\begin{array}{l}\text { Dapat menambahkan, } \\
\text { melihat detail, } \\
\text { mengubah, dan } \\
\text { menghapus data } \\
\text { penerimaan pangan }\end{array}$ & Berhasil \\
\hline 9. & $\begin{array}{l}\text { Mengelolah } \\
\text { pengembalian } \\
\text { pangan }\end{array}$ & Admin & $\begin{array}{l}\text { Menambahkan, } \\
\text { melihat detail, } \\
\text { mengubah, dan } \\
\text { menghapus data } \\
\text { pengembalian pangan }\end{array}$ & $\begin{array}{l}\text { Dapat menambahkan, } \\
\text { melihat detail, } \\
\text { mengubah, dan } \\
\text { menghapus data } \\
\text { pengembalian pangan }\end{array}$ & Berhasil \\
\hline 10. & $\begin{array}{l}\text { Melihat } \\
\text { pemesanan } \\
\text { pangan }\end{array}$ & Supplier & $\begin{array}{l}\text { Melihat data } \\
\text { pemesanan pangan } \\
\text { dari pasar }\end{array}$ & $\begin{array}{l}\text { Dapat melihat data } \\
\text { pemesanan pangan } \\
\text { dari pasar }\end{array}$ & Berhasil \\
\hline 11 & $\begin{array}{l}\text { Melihat } \\
\text { pengembalian } \\
\text { pangan }\end{array}$ & Supplier & $\begin{array}{l}\text { Melihat data } \\
\text { pengembalian pangan } \\
\text { dari pasar }\end{array}$ & $\begin{array}{l}\text { Dapat melihat data } \\
\text { pengembalian pangan } \\
\text { dari pasar }\end{array}$ & Berhasil \\
\hline 12. & $\begin{array}{l}\text { Mengelolah } \\
\text { transaksi } \\
\text { penjualan }\end{array}$ & $\begin{array}{l}\text { Admin, Pegawai } \\
\text { Pasar }\end{array}$ & $\begin{array}{l}\text { Menambahkan, } \\
\text { melihat detail, } \\
\text { mengubah, dan } \\
\text { menghapus data } \\
\text { penjualan }\end{array}$ & $\begin{array}{l}\text { Dapat menambahkan, } \\
\text { melihat detail, } \\
\text { mengubah, dan } \\
\text { menghapus data } \\
\text { penjualan }\end{array}$ & \\
\hline 13. & $\begin{array}{l}\text { Laporan Stok } \\
\text { Pangan }\end{array}$ & $\begin{array}{l}\text { Admin, Kepala } \\
\text { Pasar }\end{array}$ & $\begin{array}{l}\text { Melihat data laporan } \\
\text { stok pangan }\end{array}$ & $\begin{array}{l}\text { Dapat melihat data } \\
\text { laporan }\end{array}$ & Berhasil \\
\hline 14. & $\begin{array}{l}\text { Laporan } \\
\text { Pangan } \\
\text { Masuk }\end{array}$ & $\begin{array}{l}\text { Admin, Kepala } \\
\text { Pasar }\end{array}$ & $\begin{array}{l}\text { Melihat data laporan } \\
\text { pangan masuk }\end{array}$ & $\begin{array}{l}\text { Dapat melihat data } \\
\text { laporan }\end{array}$ & Berhasil \\
\hline 15. & $\begin{array}{l}\text { Laporan } \\
\text { Pangan } \\
\text { Keluar }\end{array}$ & $\begin{array}{l}\text { Admin, Kepala } \\
\text { Pasar }\end{array}$ & $\begin{array}{l}\text { Melihat data laporan } \\
\text { pangan keluar }\end{array}$ & $\begin{array}{l}\text { Dapat melihat data } \\
\text { laporan }\end{array}$ & Berhasil \\
\hline 16. & Logout & $\begin{array}{l}\text { Admin, Supplier, } \\
\text { Pegawai Pasar, } \\
\text { Kepala Pasar }\end{array}$ & $\begin{array}{l}\text { Mengautentikasi diri } \\
\text { keluar sistem }\end{array}$ & $\begin{array}{l}\text { Dapat keluar dari } \\
\text { sistem }\end{array}$ & Berhasil \\
\hline
\end{tabular}

\section{Kesimpulan Dan Saran}

\subsection{Kesimpulan}

Berdasarkan hasil dari pembuatan sistem supply chain management pengolahan pangan pangan penerima KJP di Pasar Jaya Wilayah Mampang Prapatan berbasis Web yang telah dilakukan, dapat disimpulkan sebagai berikut.

1) Sistem supply chain management pengolahan pangan penerima KJP di Pasar Jaya Wilayah Mampang Prapatan berbasis Web ini, data pangan sudah bekerja dengan baik sehingga dapat menambahkan, mengubah dan menghapus data melalui akun admin (Pihak Pergudangan).

2) Sistem supply chain management pengolahan pangan penerima KJP di Pasar Jaya Wilayah Mampang Prapatan berbasis Web ini, pencatatan penjualan pangan sudah efisien untuk melakukan proses 
menambahkan, mengubah, menghapus dan mencetak data melalui akun admin (Pihak Pergudangan) dan pegawai (Pihak Penjualan).

3) Sistem supply chain management pengolahan pangan penerima KJP di Pasar Jaya Wilayah Mampang Prapatan berbasis Web ini, sudah menyediakan halaman utama untuk melihat stok pangan yang tersedia di Pasar Jaya Mampang Prapatan tanpa harus login.

\subsection{Saran}

Penulis berharap kedepannya penelitian ini dapat dikembangkan dengan menambahkan beberapa fitur untuk mencatat perjalanan pada pengiriman pangan dari supplier ke Pasar Jaya Mampang Prapatan, dapat menambahkan fitur pemberitahuan atau notifikasi dari kegiatan pemesanan, pengembalian, dan penerimaan pangan, serta dapat meningkatkan ke sistem yang dinamis.

\section{Referensi}

[1] Arif, Muhammad. 2018. Supply Chain Management. Yohyakarta : Deepublish.

[2] Pressman, RS. 2010. Software Engineering: A Practitioner's Approach, 7th editon. McGraw-Hill, New York.

[3] Pujawan, I Nyoman \& Er, Mahendrawathi. 2017. Supply Chain management - Edisi 3. Yogyakarta : ANDI.

[4] Sugiarti, Yuni. 2013. Analisis \& perancangan UML (Unifed Modelling Language) generated VB.6. Yogyakarta : Graha Ilmu.

[5] Taufiq, Rohmat. 2013. Sistem Informasi Manajemen. Yogyakarta : Graha Ilmu 